\title{
Sebastian Peters
}

\section{Domestication of planning ideas}

\author{
The case of shared space
}

\begin{abstract}
New planning ideas, ranging from design concepts to large-scale development policies, are inherently challenging because they involve changes to prevailing thoughts and practices. However, over time, they are subjected to translations and moulded to discourses held in various contexts, often resulting in conceptual distortion. This study attempts to contribute to the theorization of translating planning ideas by proposing the concept of domestication as a means to understand such distortion. An analysis of one such challenging idea, shared space, serves to illustrate domestication and assess its usefulness.
\end{abstract}

Keywords: planning ideas, idea translation, idea domestication, discourse, shared space.

\section{Introduction}

By nature, new planning ideas pose challenges to prevalent thoughts and practices. The literature has witnessed ideas that are rather radical and may even question the conceptual basis of longestablished and institutionalized practices. One such idea is that of shared space for urban streets, which has countered hegemonic discourses and proposed an alternative understanding of streets and the principles on which they should be planned and designed. Simply, yet provocatively put, the idea advocates the abandonment of conventional means of traffic regulation. More specifically, it promotes the view that the engineered control of traffic in central urban streets is widely redundant because it suppresses the sociality of urban spaces. The idea suggests the reconceptualization of public spaces and argues that the point of departure for such spaces should be urban sociality, not issues such as safety and efficiency (Ben Hamilton-Baillie, 2008a; Engwicht, 2005; Pilz, 2011). These issues are expected to naturally fall into place as beneficial side-effects of sociality-based planning and designing. The idea also rejects the marginalization of social spaces to certain areas, thus opposing the common approach of segregating central urban spaces into functional categories as per transport engineering principles.

In recent years, the shared space idea has found much support on an international scale and become central to professional debates on urban planning with focus on traffic planning. However, the concept has also been subjected to discursive processes of conceptual translation. Various scholars (Franklin \& Tait, 2002; Healey, 2012; Lennon, 2015; Tait \& Jensen, 2007; van Duinen, 2015) have investigated the limitations of the translation of planning and design ideas and drawing on their theorizations, this study argues that such processes can change an idea to the extent of it losing its core meaning.

Planning ideas are often 'packed up' (Healey, 2012, p. 195) and passed on as planning tools and solutions to legitimate planning problems. In this sense, such ideas span (Healey, 2012; Tait \& Jensen, 2007) across not only geographical domains but also the realm of multidisciplinary professions and established viewpoints. However, during this process of translation into transferrable and universally applicable concepts, such ideas are likely to become distorted and 
'lose their critical edge' (Healey, 2012, p. 195). This weakens the ideas as a means to bring about a shift they were originally intended to achieve.

Focusing on this problem, this study aims to offer a new theoretical concept, domestication, and explore it as an analytical tool that complements existing theorization on the translation of ideas. In doing so, it contributes to a better understanding of factors at risk when planning ideas are translated. The concept of domestication highlights that existing thinking and practices tend to contain ideas and places emphases on their distortion.

A good case to explore the domestication concept is the shared space idea. Besley, for example, laments that shared space is too commonly understood as a mere design solution, and thus, it wider implications, such as a 'new direction in thinking about the public realm' (Besley, 2010 , p. 20) are overlooked. She, therefore, asserts the need for increased focus on the 'more progressive and philosophical beginnings' (p. 2) of the idea. Her critique is that implementation debates on the idea suffer from overemphasis on mere design perspectives, leading to the marginalization of the original intentions of shared space.

The understanding and definitions of shared space widely vary from being a planning philosophy to a street design template. From a technical perspective, shared space is a design solution for streets and squares mostly in central town or urban areas. Many shared space schemes are characterized by an open streetscape which does not segregate transport modes as well as a levelled surface and minimized use of standardized devices for traffic control, such as surface markings, curbs, signals, handrails or traffic signs. The most challenging aspect of shared space is its claims to serve as a catalyst for socio-spatial self-organization, rendering conventional traffic engineering redundant.

Since its pioneers presented the idea (Hamilton-Baillie \& Jones, 2005; Karndacharuk, Wilson, \& Dunn, 2014; Shared Space, 2005; 2008a), discussions on shared spaced have been extended to the planning domain on a local, national, and international scale and triggered much debate among experts and in a wider public context. These debates have prompted academic research, reports, guidelines, and policies, which provide an empirical basis to trace domestication.

The following section elaborates on the concept of domestication in the context of existing approaches towards the translation of planning ideas. The section after provides a brief overview of various methodological steps adopted in this study. Next, a closer examination of shared space is presented, with focus on challenges in current thoughts and practices and the impact of domestication on these challenges. The final section summarizes the conclusions and raises critical questions regarding the domestication concept.

\section{Theoretical framework for domestication of ideas}

This section outlines the theoretical basis for the domestication of challenging planning ideas. The concept should not be confused with domestication theory in science and technology studies, which explore how people adopt new technologies and integrate them in their everyday lives. These studies highlight the role of users in constructing meaning and identifying a status from the adoption of new technologies in their daily lives (e.g. Berker et. al 2007; Sørensen, 2006). By contrast, this study uses the concept to address how design and planning ideas are adopted and circulated within a professional realm, thus contributing to existing approaches on the process (Beauregard, 2005; Healey, 2012; Kooij \& Lennon, 2015; Tait \& Campbell, 2000; Van Assche, \& Lagendijk, 2014; van Duinen, 2015). Further, these accounts vary in their use of 'concept' and 'idea'. This study views planning 'ideas' as a more generic phenomenon than planning 'concepts', which is rather a type of idea. According to Healey (2012), other types of planning ideas may take 
the form of spatial objects, planning instruments, governance processes, analytical tools and theories, all aiming to directly or indirectly influence planning practices. The scale of planning ideas widely ranges from abstract and general policy levels (e.g. compact cities or urban villages) to more specific ones such as design concepts for urban structures such as shared space.

As for whether such ideas should be referred to as 'innovative', 'challenging' or simply 'new', this study assumes that emerging planning ideas have inherent characteristics that challenge contemporary thinking and actions. While this viewpoint distinguishes new ideas from prevailing ones, it is not entirely adequate to associate them with 'newness' because planning ideas are often challenged in context of older ones. Rather than arguing whether an idea is new, this study highlights that emerging ideas suggest a change in current thoughts and practices. In addition, an idea does not need to be innovative in the conventional sense of presenting a concept that has never existed before.

Healey (2012) theorizes that modern planning, including the emergence and continuation of planning ideas, tends to be driven by motivation to offer universally applicable solutions and that such a tendency could cost planning ideas their critical edge. However, Healey addresses this as a general concern to prompt practitioners to be critical and reflective when handling ideas and does adopt an in-depth approach to these processes of translation. Tait and Jensen present the concept of traveling ideas (Tait \& Jensen, 2007) as a theoretical approach that aims to 'provide a framework of how planners' ideas are disseminated and to understand their ability to insert them in diverse places and spaces' (p. 108). They draw on actor-network theory and discourses on analytical concepts to theorize the mobilization and translation of planning ideas such that they are embedded in new contexts. Their study mainly focuses on the mechanisms underpinning the process of embedding ideas in a given context. A key conclusion of their study is that planning ideas cannot be generalized across distances and locations; rather, efforts are needed to make ideas transferrable and the concerned actors receptive to them. In other words, transferring planning ideas to other locations warrants 'de-contextualization' and then, 're-contextualizaion' (Czarniawska \& Joerges, 1996, p. 26). Tait and Jensen's (2007) theorization partly builds on Csarniawska and Joerges' concepts, who term these processes as 'disembedding' and 'reembedding' of ideas, thereby avoiding the theoretically problematic claim that ideas can be without a context.

These approaches are useful in highlighting that translation helps define the process and dynamics behind the dissemination of ideas. Nevertheless, they can be strengthened by adopting a more critical perspective that focuses on the factors at risk in these processes. van Duinen (2015) takes such an approach and questions the position that planning ideas, which she calls 'innovative concepts', are by default, powerful tools that contribute innovative momentum to policy arenas. Further, van Duinen argues that planning ideas tend to become 'encased' (p. 2) in traditional planning discourse, consequently losing much of their initial purpose. In line with Tait and Jensen, she attributes this to the dependence of innovative planning ideas on the support of different actors to gain momentum; this support is gained by presenting the idea within the context of existing discourses, like an answer to known problems, thereby altering the persuasiveness of the idea. Therefore, the 'curbing' (p. 18) of innovative ideas seems to be an inevitable trade-off in which the innovative momentum of the idea itself is at stake. Also taking a discursive perspective, Lennon (2015) describes this process as giving 'currency' to innovative policy concepts. However, in contrast to van Duinen, Lennon presents the discursive transformation of ideas as strategies which give them persuasiveness and as a precondition for innovative ideas to gain momentum. 
This study introduces the concept of domestication of planning ideas and explores it from an analytical perspective. Domestication is the process in which new planning and design ideas are adjusted to prevailing thoughts and practices within the professional realm such that they lose their critical momentum. From an analytical perspective, the concept can be used to identify this critical momentum. Applying a domestication perspective means investigating the process of adjustments of ideas by asking two core questions. First, how does the idea challenge prevailing thoughts and practices in the professional realm? Second, how do professional versions of the idea translate and represent this challenge?

Since domestication occurs in the professional realm, it is not bound to a geographical context or scale; that is, it could have local, national, or international dimensions. The abovementioned studies, however, focus on local and often political struggles of implementing ideas; in particular, they explore the translation of ideas from the theoretical to implemented level. The domestication perspective, on the other hand, addresses how ideas change when passed on within the professional realm. However, this does not indicate that domestication is 'context-less' or professional discourses are not political. Rather, this study aims to narrow the focus to the community of professional actors consider key players in defining and representing expert knowledge. These include architects, planners with different expertise, engineers, project managers, consultants, planning agents, and other specialists engaged in producing and realizing plans. Politicians, interest groups, and the public are also important actors, although this study focuses on professionals.

While the analytical focus is on the professional realm, I do not consider domestication as a process driven by a single actor or group; rather, I view it as a discursive process and further explain this in the following sub-section.

\section{Domestication as a discursive process}

Domestication highlights that ideas are not simply translated to identify an expression in professional terms; rather, they must be adjusted towards established disciplinary ways of thinking. To gain legitimacy, an idea must fulfil certain conceptual criteria that are based on values and judgment of the ideal way of working. Domestication emphasizes that fitting to existing discourse through translation can be problematic if ideas are softened and lose their initial meaning. Here, discourse is understood as a dynamic process that shapes and enables social reality (Jäger \& Maier, 2009), for example, how we think, talk and act about certain phenomena. A single discourse may be composed of a collective stock or reservoir of knowledge (Keller, 2011) shared and reproduced within a certain group of actors such as those engaged in planning at the professional level. Discourse also influences how these actors share this reservoir of knowledge, think, talk, and act upon new ideas.

However, there are multiple discourses enabling a single social reality, which eventually get entangled with and influence each other (Jäger \& Maier, 2009). The understanding of multiple interacting discourses leans on Foucault's notion of plurality of discourses and their interdependency, as explained by Hajer (1995). This study argues that a dynamic interplay of discourses occurs when ideas are passed on and translated. van Duinen follows Kooij et al. (2014) in asserting that 'open concepts' (p. 84) are particularly prone to change through such interplay because they are vague and flexible, thus serving as 'enablers' (p. 84) for existing discourses.

In the domestication process, existing discourses re-frame an idea using recognized terms and then legitimize it as playing a role in the wider professional and public debate, eventually rendering the idea part of the debate. Discourses can convey credibility of knowledge and 
persuasiveness of arguments, where ideas serve as vehicles facilitating a discourse (Biddulph, Franklin, \& Tait, 2003; Kooij et al., 2014) and vice versa. Applying the domestication concept for analyses involves paying considerable attention to the outcome and critically evaluating how much of the ideas' initial potential remains once the translation process is complete.

I assume that planning ideas are not value neutral and promote an agenda built on certain assumptions. The extent to which this challenges common practices varies and so does the degree of domestication. However, these variations are more likely to occur when ideas encounter planning fields characterized by strong political agendas and disciplinary traditions, which is the case with transport planning, an example used in this study. This subfield of planning is dominated by engineering disciplines and guided by instrumental approaches that have strong resistance to conceptual and methodological change. Many scholars have noted this being particularly strong when determining the validity of methods and recognizing the types of field knowledge (Flyvbjerg, 2007; Packer, 2003; Røe, 2000; Sheller, 2011; Urry, 2004). Field knowledge is typically represented by widely accepted techniques and approaches as rhetorical means to reducing uncertainty and making the future appear more manageable (Langmyhr, 2000, p. 673) ${ }^{\mathrm{i}}$. This includes the framing of certain transport planning problems using professional and seemingly universally accepted terminology such as lack of congestion, traffic migration or insufficient traffic safety.

Such framing has important implications for the present argument on disciplinary domestication. It means that to gain recognition within transport planning, a challenging idea must be framed as a solution to professionally recognized problems to attain Lennon's 'currency' (2015, p. 1) within the concerned field. From this perspective, domestication seems almost inevitable in determining, for example, instances in which ideas such shared space challenge existing governance approaches to public space and question prevailing power constellations.

Examples of typical practices contributing to domestication include mapping, designing and developing alternatives, formulating policy, conducting planning processes, performing impact assessments, writing planning documents and developing guidelines. These practices present hints of domestication in the form of text. Text mirrors commonly recognized methods of knowing and creating 'particular forms of knowledge, providing legitimacy for particular spatial strategies' (Richardson \& Jensen, 2003, p. 12). I regard these texts as attempts to reframe ideas because they reflect prevailing values, widespread terminology or references to legitimate methods and sources of knowledge.

An important consideration for shared space is that the translation of an idea includes the simplification of elements that do not fit dominant discourses. By contrast, other parts of the idea that fit prevailing approaches and methods are often emphasized, partially because of advocates seeking to provide counter-evidence to criticism. Moreover, existing ways of thinking and acting can be so formative of the translated version that they overshadow challenging elements of an idea.

\section{Method: detecting domestication in texts}

Debate and efforts to realize shared space projects across the world (predominantly north-western Europe and to a lesser degree, Australia, New Zealand, the United States and Canada) have created a text corpus on the idea. Even though discussions are often focused on single projects or national debates, this literature serves as a knowledge pool at an international scale. Thus, the texts produced by professionals involved in planning and designing or researching shared space presents an empirical basis for this present study (see Table 1 and Appendix 1 for a detailed overview). 
The data collection focused on reviewed articles and published conference papers on shared space. Then, references within these texts, including those to reports, policies and guidelines, were reviewed, until no new reference promised further insight. This snowball approach was used until the corpus of texts was assumed to be large enough for a robust and comprehensive analysis. This strategy allowed me to identify the most central references within the knowledge pool.

The empirical basis for this paper is a collection of about 82 documents that focus on the idea of a shared space from a professional perspective (Table 1). The texts are heterogeneous in terms of not only approaches but also types of documentation referenced such as policy, official guidelines, scientific article, conference paper or case collection.

Table 1: Types and number of domestication texts analysed.

\begin{tabular}{|l|l|}
\hline Type of literature & Number of texts \\
\hline Reports, policy and guidelines & 30 \\
\hline Journal articles & 15 \\
\hline Papers (e.g. conference papers and lectures) & 17 \\
\hline Books & 1 (17 contributions) \\
\hline Thesis & 3 \\
\hline Total & 66 (82 contributions) \\
\hline
\end{tabular}

Since this study focuses on professionals as key players in the domestication of the shared space idea, public media articles or statements by politicians or personal actors are excluded. While actors such as politicians certainly influence practices and perspectives within the field, I consider professional discourses to offer a more direct reflection. A factor limiting the scope of literature search was language: I was able to read documents in English, German, Norwegian, Swedish or Danish.

All texts can be categorized between the two extremes of being a challenge to common thoughts and practices and being a domesticated version. Thus, a strongly fitted text may have traces of challenging, non-domesticated elements, and vice versa.

The critical interrogation of each individual text was based on two key questions, which is one way of identifying discursive elements linked to domestication in the text corpus:

- How does the idea of shared space challenge prevailing thoughts and practices in the professional realm?

- How do professional versions of the idea translate and represent this challenge?

In addition, I articulated the following two sub-questions to sharpen the focus of the second research question:

- How are users of space represented?

This question helps trace domestication since in typical transport planning terms, users are represented as technical and quantifiable units. On the other hand, I adopt a more socially oriented account, which views users in cultural terms, needs and activities as well as social relations:

- How is public urban space represented? 
With emphasis on functionality, space as a technical unit or spatial resource indicates a tendency towards domestication. On the other hand, focusing on urban space as a resource for social activity, communication or cultural productivity indicates a less-domesticated version.

Thus, the interpretative analysis of these texts focuses on determining whether and how each reframes the idea and the extent to which it simplifies, marginalizes or downplays the challenging elements of shared space.

\section{Challenges of shared space}

This section identifies the challenges shared space poses to current thoughts and practices in transport planning.

Many accounts of shared space associate its conceptual roots to the Dutch street design concept, woonerf, which dates back to the late 1960s and early 1970s, and to Joost Vàhl, a pioneer who practiced 'the deliberate integration of traffic into social space' (Hamilton-Baillie, 2008a, p. 166). Hans Monderman is often cited as a Dutch traffic engineer who was the first to realize shared space projects.

On an international scale, Hans Monderman and his colleagues launched the European Shared Space Project as part of the European Union's Interreg IIIB North Sea Region Program. From 2004 to 2008, seven municipalities in Belgium, Denmark, Germany, England and the Netherlands designed and built pilot schemes, generating a pool of shared space test cases. The concept was subsequently propagated and introduced to different parts of the world, with most resonance being observed in the implementing countries and neighbouring ones. While the concept of shared streets has been around for a while (Karndacharuk, Wilson, \& Dunn, 2014), that of shared space can be considered an outcome of a dialogue between Ben Hamilton-Baillie, a British transport planner, and Hans Monderman. Hamilton-Baillie has published some of the most frequently referenced texts on the idea (Hamilton-Baillie, 2008a, 2008b; Hamilton-Baillie \& Jones, 2005).

However, some contributions to the shared space debate distance themselves from an affirmative mainstream. Instead, they critically point to a tendency of environmental determinism (Hammond \& Musselwhite, 2013) in shared space discourses, the simplification and generalizations of user needs, the danger of excluding impaired individuals (Imrie, 2012) and political biases of texts that advocate shared space (Moody \& Melia, 2013).

In its earlier form, shared space aimed to generate sociality through urban design. It claimed that human conduct based on social knowledge and skills can enable social selforganization and promoted the idea of socially responsible citizenship. In other words, it is conceptually related to wider critiques against modernistic planning in general (e.g. Abram, 2011; Healey, 2010; Sandercock, 2000) and the field of transport planning in particular (e.g. Beckmann, 2004; Sheller, 2011; Urry, 2004). From a provoking standpoint, the idea suggests a shift in power relations in terms of governance of human encounters on the street since it suggests that prevailing means of traffic control are dispensable. From this viewpoint, the idea poses a threat to the domain of transport planning as it goes beyond suggesting an alternative design for certain user conditions. It poses questions about the decision maker for the planning, design and management of streets and the knowledge, skills and methods that are considered legitimate to guide such work.

Shared space claims that such decisions in the context of urban streets should be based on the principles of sociality (Engwicht, 2005; Pilz, 2011). The idea highlights urban street design as a means to influence sociality through design, rather than to solve technical problems. This 
emphasis on the relationship between spatial and social is the challenge that the idea poses to prevailing thoughts and practices. Accepting such an approach would allow new actors to play a role in defining how transport space should be defined, both professionally and in governance terms. More specifically, new actors would be prioritized and contribute to the definition of the resources needed for such a space. Disregarding the sociality claim and translating shared space into an engineering project serves to maintain the legitimacy of the engineering discipline to control traffic.

However, it is important to not perceive the domestication of shared space as a strategy pursued by certain actors to protect established disciplinary borders or power structures nor are the domesticators meant to be conservative transport engineers, defending their domain against challenging ideas. Rather, domestication should be viewed as a diffuse discursive process within a multidisciplinary transport planning field, where professional debate must respond to a wider public agenda. In addition, it can be used within transport planning to identify the most central and pressing issues that warrant focus, such as traffic safety and transport efficiency. Shared space advocates, who are often transport planners themselves, are forced to produce counter-evidence in response to criticisms regarding these pressing issues. Accordingly, the shared space debate and emerging literature are being gradually reframed in the context of dominant transport and traffic discourses. This leads to a domesticated version of shared space as an answer to existing and legitimate problems.

\section{Representation of sociality in shared space texts}

At present, disputes over shared space regarding, for example, traffic safety and exclusion of diverse user groups, have been a key driver of systematic knowledge production on the topic. The idea has become a key topic of international and national conferences, seminars, workshops and traffic fora. However, related research is mainly concerned with the development of planning and design guidelines. For instance, as this paper is being written, research is being conducted in Norway and supported by the Norwegian Road Directorate with an aim to defining shared space as a design concept, despite the existence of ample implementation experiences and design guidelines in neighbouring countries.

Studies have presented the idea as both a challenge and more in line with existing approaches. An example of a non-domesticated version is a report resulting from the abovementioned European project (Shared Space, 2005, 2008a, 2008b). The report was written and published by members of the project group and summarized experiences from the various pilot projects. It made explicit statements about the role of sociality in developing alternative ways to plan and design public urban spaces. Further, it placed strong emphasis on reconquering public spaces as an arena for social life; for example, the report considered public spaces to be the 'heart' (Shared Space, 2005, p. 9) of society:

The layout of the public space tells us what society looks like, who forms part of it, how people deal with each other and what they consider important. It is a window on and a mirror of society.

The quote clearly advocates shared space as a way of enabling the social qualities of public urban spaces. It gives much weight to sociality as a key factor in maintaining order in public life.

Another example is Hamilton-Baillie's (2008a) article, 'Shared space: reconciling people, places and traffic'. This study emphasizes the socio-spatiality challenge of shared space as an opportunity to change the 'built environment in ways that encourage diversity, distinctiveness, urban quality and civility' (p. 162). It frequently refers to 'complex informal social protocols' (p. 
162) substituting conventional traffic control. As in the previously cited quote, the sociocultural significance of public space has considerably more weight than its technical organization. In addition, it presents the view that the technical organization of public space, especially in the context of traffic, should be carefully guided by the sociocultural qualities of public space, rather vice versa. Thus, shared space is said to be 'the integration of traffic into the social and cultural fabric of the built environment' (p. 169).

Pilz (2011) also discusses the challenges of shared space and underlines the importance of complex relationships between people and their urban environment:

Public space should be maintained as sensible changes to lived social structure; locals should be able to perceive it as a stage that becomes individually and communicatively appropriated and played upon. Until then, the public space will not do justice to its function in the complex fabric of public life: It must mirror society. (p. 5, author's translation from German).

Gerlach, Boenke, Leven, and Methorst (2008) presented the idea as a critique to prevailing approaches and argued for the deliberative effect of design that allows latent social responsibility, which is normally constrained by standard practices:

...the concept relies on political responsibility and participation, whereas more personal responsibility from citizens is required for both the planning of and daily encounters with the new traffic situation. Hence, shared space aims at realizing a double quality - a spatial and a democratic quality'. (p. 62, author's translation from German).

From this perspective, shared space are enacted by socially active users who act as socially responsible persons regulating their behaviour according to common social norms and rules of human conduct (e.g. Edquist \& Corben, 2012; Engwicht, 2005; Jones \& Young, 2010; Karndacharuk, Wilson, \& Dunn, 2013; Pilz, 2011). Order primarily results from social encounters and to a lesser degree, is conditioned by the physical environment and design. This perspective highlights civility as an important precondition for shared space to work.

In contrast, domesticated versions highlight the technical limitations of the idea. Table 2 exemplifies a typical outcome of domestication, demonstrating the differences between the more radical version of shared space and its domesticated version. The table is derived and translated from a study report written for an umbrella organization for German insurance companies (Gerlach, Ortlepp, \& Voß, 2009).

Table 2: Ten factors necessary for the success of the implementation shared space in Germany (Derived and translated from Gerlach et al. (2009) and earlier presented in Peters (2011)).

\begin{tabular}{|l|l|l|}
\hline Issues & $\begin{array}{l}\text { General shared space idea (by } \\
\text { Hans Monderman) }\end{array}$ & $\begin{array}{l}\text { Suggestions for Germany by } \\
\text { Gerlach et al. (2009) }\end{array}$ \\
\hline Application area & All streets & $\begin{array}{l}\text { Streets with lingering or stay } \\
\text { function } \\
\text { maximum length 300 meters }\end{array}$ \\
\hline Entrance signs/label/marker & None & Necessary \\
\hline Mobility arrangement & Mixed use, all modes & $\begin{array}{l}\text { Safe areas for pedestrians, safe } \\
\text { crossings, speed reduction measures }\end{array}$ \\
\hline
\end{tabular}




\begin{tabular}{|l|l|l|}
\hline Issues & $\begin{array}{l}\text { General shared space idea (by } \\
\text { Hans Monderman) }\end{array}$ & $\begin{array}{l}\text { Suggestions for Germany by } \\
\text { Gerlach et al. (2009) }\end{array}$ \\
\hline $\begin{array}{l}\text { Participation of public and } \\
\text { interest groups in planning and } \\
\text { design process }\end{array}$ & Always & Always \\
\hline Traffic volume & No default limitation & $\begin{array}{l}\text { Max. 14,000 vehicles/day, limited } \\
\text { heavy vehicle traffic, numerous } \\
\text { pedestrians and cyclists }\end{array}$ \\
\hline Speed & No default limitation & Max 30 km/h \\
\hline Right of way & Left gives way to right & Left gives way to right \\
\hline Signals, signs and markings & None & If necessary to provide safety \\
\hline Parking rules & None & Parking not permitted \\
\hline $\begin{array}{l}\text { Children play on street or driving } \\
\text { surface }\end{array}$ & Permitted & Prohibited \\
\hline
\end{tabular}

* The length criterion is not found in the original table but mentioned in the report (Gerlach et al., 2009, p. 29).

The suggestions in this overview reflect a far more technically oriented approach driven by a rationale to guard traffic safety using conventional methods than a radical version of the idea. In addition to the differences in how issues (first column) are addressed, the definition of relevant issues gives insight into the domestication of shared space. The official German guidelines for shared space implementation later adopted and extended these recommendations but with more technical detail (Forschungsgesellschaft für Straßen \& Verkehrswesen, 2011). These guidelines recommend a relegation of shared space to areas that fulfil certain technical criteria, such as pedestrian footfall, traffic volumes and type of intersections. It is presented as a so-called 'knowledge document' (p. 21) that prescribes how specific technical issues should be handled. Positioning shared space as a concept in professional street design, the report emphasizes how it fits to German traffic law and a range of technical requirements for its implementation. It also specified social dimensions such as the creation of a 'pleasant atmosphere' and the facilitation of 'mutual consideration' (p. 4) among traffic participants, which are similar to those in the British guidelines for shared space (see the list below), as an outcome of the design, which can be achieved by fulfilling technical requirements that influence the streetscape:

- The abandonment of curbs using alternative subdividing elements to indicate permitted areas for vehicle movement.

- Matching the layout of surfaces of edge spaces and driveway, though without completely abandoning their demarcation.

- Extensive renunciation of markings and signs.

- Maintenance of clear view between vehicle traffic and pedestrians, specifically with regard to parking (p. 5, author's translation from German).

Typically, documentation a domesticated shared space avoids the challenge of considering complex social dynamics by expressing them in established categories and thus, a known function of public space, called sense of place. Sense of place is an expression commonly used to highlight different functions that are incompatible by nature, such as the place and traffic functions: 
Every street represents a balance between movement (the capacity to accommodate through traffic) and a sense of place (the quality which makes a street somewhere to visit and spend time in, rather than to pass through). Shared Space is a way of enhancing a street's sense of place while maintaining its ability to accommodate vehicular movement (Department for Transport, 2011, p. $6)$.

A typical domesticated perspective portrays the sense of place primarily as dependent on designable elements. For example, the above-mentioned British design guidelines derived its definition of place function on the Manual for Streets:

The place function is essentially what distinguishes a street from a road. The sense of place is fundamental to a richer and more fulfilling environment. It comes largely from creating a strong relationship between the street and the buildings and spaces that frame it. [...] The choice of surface materials, planting and street furniture has a large part to play in achieving sense of place (Bradbury et al., 2007, p. 17).

From an analytical perspective, the above examples illustrate how professionally recognized terminology is used to convey the credibility of knowledge and persuasiveness of arguments.

However, there are largely vague explanations of how users participate in creating or relate to sense of place. The term place function and sense of place are applied as conceptual shortcuts that promise 'pedestrian comfort' (Department for Transport, 2011, p. 16), 'vibrant spaces' (p. 11) or 'sympathetic behavior of motorists' (p. 7). From a state-of-the-art perspective, responsible behaviour is portrayed as the natural outcome of design and layout, rather than a result of changed socio-spatial dynamics. Users are typically portrayed as a homogeneous group that are technically defined on the basis of transport mode, not sociocultural dimensions. The social implications of shared space such as 'cooperation' (Schönauer, Stubenschrott, Schrom-Feiertag, \& Menšik, 2012) or changes in community texture (Anvari, Daamen, Knoop, Hoogendoorn, \& Bell, 2014) are mainly considered technical and quantitatively measurable terms such as pedestrian footfall per time unit or density per area.

The above examples demonstrate the simultaneous working of different ways of domestication within the shared space idea. First, the idea is translated into a tool to deal with known issues in dominant transport planning discourse, such as safety or transport efficiency. Second, the challenge of the idea is often simplified or masked by expressing it with widely accepted concepts such as sense of place. Third, the realization of the idea is, to a certain extent, marginalized by the definition of (mainly technical) boundaries for exceptional cases in which it may be applicable.

\section{Concluding remarks}

This analysis illustrated the use of the domestication concept as a tool to critically examine how through professional discourses, ideas are translated and as a result, lose their critical momentum. In the case of shared space, this critical momentum was to bring a conceptual shift to street design. It argues for the integration of a sociality perspective into street design that aims at a stronger recognition of how design influences sociality in public spaces. However, more recent literature about shared space seems to bypass this challenge and reframe the idea as a technical concept to enable a functional relationship in which technical issues play a dominant role, while the social implications of the design are only loosely addressed and sometimes, even absent. 
From this, I conclude that domestication is a useful analytical concept that makes this process more explicit by highlighting the consequences of the translation process. However, I succeeded only partly in exploring the concept. While the investigation affirms shared space as a case of domestication, the concept itself and the method I use to operationalize it need further development. For example, one might be sceptical about the domestication concept and argue that it is difficult to avoid a certain degree of translation if ideas are to be realized at all. Further, it can be asserted that all fields of planning, as in the case of transport planning, cannot be treated as static, innovation-resistant systems; this change is essentially driven by the motivation to realize ideas, not distort them. Most shared space researchers would agree with this viewpoint. Therefore, translation may even be considered a precondition to operationalize ideas and foster their potential to bring about change. Transport planners generally aim at meeting the needs of travellers and view this practice as a service to society. A domestication approach should, therefore, avoid singling out any professional discipline, such as transport planning, for being deconstructive solely on the basis of its attempts to implement ideas using expertise.

This critique raises questions about the significance of domestication and its contribution beyond labelling the phenomenon. I would argue, however, that it presents a useful critical perspective, both in theory and practice, because it highlights what is at stake when ideas are translated. Such a perspective poses a range of other questions that help illuminate the process of translation and its consequences; for example, who are the domesticators? Are ideas domesticated by intention? Is it an unfavourable, but unavoidable, by-product of the ideas' implementation? A possible answer is that domestication does not deliberately occur to impair ideas, but is as an unavoidable discursive mechanism.

This does not indicate that domestication is an actor-less and context-less automatism. This, in fact, would disburden potential domesticators of their responsibility to be aware of how to deal with challenging ideas. It is increasingly difficult, and possibly inadequate, to tie domestication to a single actor, group of actors, profession or discipline. The question of who is also linked to the question of where. Domestication emerges not only in local discourses that influence the realization of planning ideas but across geographic scales. Nevertheless, as in the case of shared space, it eventually materializes in specific context, such as in design guidelines or planning policies, thus impacting decision making at a local level.

The key question is whether domestication should be avoided or is it an unavoidable cost of change? Translation may be inevitable, if not necessary, but it should take a critical approach if the idea is meant to make a difference since translation is not the same as domestication. Some translations may occur in the course of dissemination and implementation of ideas, but this does not suggest that no theoretical and practical measure can be taken. The concept of domestication presents a view that is of significance to an increasingly multi-disciplinary planning field and falls directly on the interface of academia and practice.

For practitioners working with ideas such as shared space, this study offers a critical understanding for guidelines or policies as a product of translation with domestication as a possible consequence. This can make them more aware of the normative implications of such guidelines and policies. It also challenges practitioners to become more critical and search for the critical momentum of ideas while avoiding excessive focus on technical realizations. For planning academics, such a critical analysis is useful to further their understanding about the consequences of translating planning ideas and the possible way to research the topic. Finally, it helps map and uncover parts of ideas that are prone to domestication if they are not based on solid theoretical and empirical grounds, as in the case of the idea of sociality in shared space. 


\author{
Sebastian Peters \\ Postdoc, Ph.d. \\ Department of Urban and Regional Planning, \\ Faculty of Landscape and Society, \\ Norwegian University of Life Sciences (NMBU), Ås, Norway \\ sepe@nmbu.no
}

\title{
References
}

Abram, S. (2011). Culture and planning. Farnham: Ashgate Publishing, Ltd.

Anvari, B., Daamen, W., Knoop, V. L., Hoogendoorn, S. P., \& Bell, M. G. (2014). Shared Space modeling based on social forces and distance potential field. In U. Weidmann, U. Kirsch, \& M. Schreckenberg (Eds.), Pedestrian and evacuation dynamics (p. 907). Switzerland: Springer Science \& Business.

Beauregard, R. A. (2005). From place to site: negotiating narrative complexity. In C. Burns \& A. Kahn (Eds.), Site matters: design concepts, histories, and strategies (pp. 39-58). New York: Routledge.

Beckmann, J. (2004). Mobility and safety. Theory, Culture \& Society, 21, 81-100. 10.1177/0263276404046062

Berker, T., Hartmann, M., Punie, Y., \& Ward, K. (2007). Domestication of media and technology. Maidenhead: McGraw-Hill Education.

Besley, E. (2010). Kerb your enthusiasm - why shared space doesn't always mean shared surface, and other stories (ISSN 1748-8338). London: The Parliamentary Advisory Council for Transport Safety.

Biddulph, M., Franklin, B., \& Tait, M. (2003). From concept to completion: a critical analysis of the urban village. Town Planning Review, 74(2), 165-193. Retrieved from: ttp://online.liverpooluniversitypress.co.uk/loi/tpr

Bradbury, A., Cameron, A., Castell, B., Jones, P., Pharoah, T., Reid, S., \& Young, A. (2007). Manual for Streets. UK: Thomas Telford Publishing.

Czarniawska, B., \& Joerges, B. (1996). Travels of ideas. In B. Czarniawska \& G. Sevón (Eds.), Translating organizational change (pp. 13-48). Berlin: Walter de Gruyter.

Department for Transport. (2011). Shared space local transport note (Vol. 1/11, pp. 55). London: Department for Transport.

Edquist, J., \& Corben, B. (2012). Potential application of Shared Space principles in urban road design: effects on safety and amenity. Retrieved from TRID: http://trid.trb.org/view.aspx?id=1143781

Engwicht, D. (2005). Mental speed bumps: the smarter way to tame traffic. Annandale: Envirobook.

Flyvbjerg, B. (2007). Policy and planning for large-infrastructure projects: problems, causes, cures. Environment and Planning B: Planning and Design, 34(4), 578-597. 10.1068/b32111

Forschungsgesellschaft für Straßen- und Verkehrswesen. (2011). Hinweise zu Strassenräumen mit besonderem Überquerungsbedraf - Anwendingsmöglichkeiten des "Shared Space"-Gedankens [Notes road spaces with special crossing requirements - Application possibilities of the Shared Space idea]. Köln: FGSV.

Franklin, B., \& Tait, M. (2002). Constructing an image: the urban village concept in the UK. Planning Theory, 1(3), 250-272. 10.1177/147309520200100304

Gerlach, J., Boenke, D., Leven, J., \& Methorst, R. (2008). Sinn und Unsinn von Shared Space - Zur Versachlichung einer populären Gestaltungsphilosophie; Teil 2 [Sense and nonsense about Shared Space-For an objective 
view of a popular planning concept; part 2]. Straßenverkehrstechnik, 52, 140-149. Retrieved from http://www.strassenverkehrstechnik-online.de/

Gerlach, J., Ortlepp, J., \& Voß, H. (2009). Shared Space, Eine neue Gestaltungsphilosophie für Innenstädte? Beispiele und Empfehlungen für die Praxis [Shared Space, a new design philosophy for city centers? Examples and recommendations for practice]. Retrieved from Unfallforschung der Versicherer: udv.de/download/file/fid/1430

Hajer, M. A. (1995). The politics of environmental discourse: ecological modernization and the policy process. Oxford: Clarendon Press.

Hamilton-Baillie, B. (2008a). Shared space: reconciling people, places and traffic. Built Environment, 34(2), 161181. 10.2148/benv.34.2.161

Hamilton-Baillie, B. (2008b). Towards shared space. Urban Design International, 13(2), 130-138. 10.1057/udi.2008.13

Hamilton-Baillie, B., \& Jones, P. (2005). Improving traffic behaviour and safety through urban design. Proceedings of the Institution of Civil Engineers - Civil Engineering, 158(5), 39-47. 10.1680/cien.2005.158.5.39

Hammond, V., \& Musselwhite, C. (2013). The attitudes, perceptions and concerns of pedestrians and vulnerable road users to shared space: A case study from the UK. Journal of Urban Design, 18(1), 78-97. $10.1080 / 13574809.2012 .739549$

Healey, P. (2010). Making better places: the planning project in the twenty-first century. Basingstoke: Palgrave Macmillan.

Healey, P. (2012). The universal and the contingent: some reflections on the transnational flow of planning ideas and practices. Planning Theory, 11(2), 188-207. 10.1177/1473095211419333

Imrie, R. (2012). Auto-disabilities: the case of shared space environments. Environment and Planning A, 44(9), 2260-2277. 10.1068/a44595

Jones, P., \& Young, A. (2010). Manual for Streets 2, Wider Application of the Principles. Retrieved from www.ciht.org.uk: http://www.ciht.org.uk/en/document-summary/index.cfm/docid/055693F6-8DB0-4BBEAA9FF1B5BC5E9412

Jäger, S., \& Maier, F. (2009). Theoretical and methodological aspects of Foucauldian critical discourse analysis and dispositive analysis. In R. Wodak \& M. Meyer (Eds.), Methods for critical discourse analysis (pp. 34-61). London: Sage Publications Limited.

Karndacharuk, A., Wilson, D. J., \& Dunn, R. C. (2013). Analysis of pedestrian performance in shared-space environments. Transportation Research Record: Journal of the Transportation Research Board, 2393, 111. 10.3141/2393-01

Karndacharuk, A., Wilson, D. J., \& Dunn, R. (2014). A review of the evolution of shared (street) space concepts in urban environments. Transport Reviews, 34(2), 190-220. 10.1080/01441647.2014.893038

Keller, R. (2011). Diskursforschung (4th ed.). Germany: VS Verlag für Sozialwissenschaften.

Kooij, H.-J., Van Assche, K., \& Lagendijk, A. (2014). Open concepts as crystallisation points and enablers of discursive configurations: The case of the innovation campus in the Netherlands. European Planning Studies, 22(1), 84-100. 10.1080/09654313.2012.731039

Langmyhr, T. (2000). The rhetorical side of transport planning. European Planning Studies, 8(5), 669-684. $10.1080 / 713666431$

Lennon, M. (2015). Explaining the currency of novel policy concepts: Learning from green infrastructure planning. Environment and Planning C: Government and Policy, 33(5), 1039-1057. 10.1177/0263774X15605939

Moody, S., \& Melia, S. (2013). Shared space: research policy and problems. Proceedings of the Institution of Civil Engineers - Transport, 167(6), 384-392. 10.1680/tran.12.00047

Packer, J. (2003). Disciplining mobility, governing and safety. In J. Z. Bratich, J. Packer, \& C. McCarthy (Eds.), Foucault, cultural studies, and governmentality (pp. 135-160). US: SUNY Press. 
Peters, S. (2011). Shared space in Reykjavik? An opportunity to rethink street design in the capital of Iceland. (Master Thesis, MSc), Reykjavik University, Iceland.

Pilz, T. (2011). Form, Halt, Respekt - Shared Space als Denkform in Architektur und Raumplanung [Shape, support, respect - shared space as a way of thinking in architecture and planning]. Retrieved from www.aaps.at: http://www.aaps.at/wp-content/uploads/2013/04/Form_Halt_respekt_Shared_Space_als_Denkform.pdf

Richardson, T., \& Jensen, O. B. (2003). Linking discourse and space: Towards a cultural sociology of space in analysing spatial policy discourses. Urban Studies, 40(1), 7-22. 10.1080/00420980220080131

Røe, P. G. (2000). Qualitative research on intra-urban travel: an alternative approach. Journal of Transport Geography, 8(2), 99-106. 10.1016/S0966-6923(99)00039-3

Sandercock, L. (2000). When strangers become neighbours: managing cities of difference. Planning Theory \& Practice, 1(1), 13-30. 10.1080/14649350050135176

Schönauer, R., Stubenschrott, M., Schrom-Feiertag, H., \& Menšik, K. (2012). Social and Spatial Behaviour in Shared Spaces. Paper presented at the REAL CORP 2012, Austria.

Sheller, M. (2011). The emergence of new cultures of mobility: stability, openings and prospects. In R. Kemp, Dudley, G., Geels, F., Lyons, G. (Ed.), Automobility in transition? A socio-technical analysis of sustainable transport. London: Routledge.

Shared Space. (2005). Shared space - room for everyone. Retrieved from www.shared.space.org: http://sharedspace.org/wp-content/uploads/2014/10/Room-for-everyone.pdf

Shared Space (2008a). Shared space - from project to process. Retrieved from www.shared.space.org: http://sharedspace.org/wp-content/uploads/2014/10/From-project-to-process.pdf

Shared Space (2008b). Shared space - spatial quality - places that attract people. Retrieved from www.shared.space.org: http://sampac.nl/EUKN2015/www.eukn.org/dsresourcecbb1.pdf?objectid=146377

Sørensen, K. H. (2006). Domestication: the enactment of technology. In T. Berker, M. Hartmann, \& Y. Punie (Eds.), Domestication of media and technology (pp. 40-61). UK: McGraw-Hill Education.

Tait, M., \& Campbell, H. (2000). The politics of communication between planning officers and politicians: the exercise of power through discourse. Environment and Planning A, 32(3), 489-506. 10.1068/a3287

Tait, M., \& Jensen, O. B. (2007). Travelling ideas, power and place: the cases of urban villages and business improvement districts. International Planning Studies, 12(2), 107-128. 10.1080/13563470701453778

Urry, J. (2004). The 'system' of automobility. Theory, Culture \& Society, 21(4-5), 25-39. $10.1177 / 0263276404046059$

van Duinen, L. (2015). New spatial concepts between innovation and lock-in: The case of the Dutch Deltametropolis. Planning Practice \& Research, 30(5), 548-569. 10.1080/02697459.2015.1076155 


\section{Appendix 1: Literature examined for domestication of shared space}

\begin{tabular}{|c|c|}
\hline Author or publisher & Title \\
\hline \multicolumn{2}{|l|}{ Articles (peer reviewed) } \\
\hline $\begin{array}{l}\text { Anvari, Bani, } \\
\text { Daamen, Winnie } \\
\text { Knoop, Victor L. } \\
\text { Hoogendoorn, Serge P. } \\
\text { Bell, Michael G. H. }\end{array}$ & $\begin{array}{l}\text { Shared Space Modeling Based on Social Forces } \\
\text { and Distance Potential Field }\end{array}$ \\
\hline Hamilton-Baillie, Ben & Shared Space: Reconciling People, Places and Traffic \\
\hline $\begin{array}{l}\text { Hamilton-Baillie, Ben } \\
\text { Jones, Phil }\end{array}$ & Improving Traffic Behaviour and Safety through Urban Design \\
\hline Hamilton-Baillie, Ben & Towards shared space \\
\hline $\begin{array}{l}\text { Gerlach, Jürgen } \\
\text { Boenke, Dirk } \\
\text { Leven, Jens } \\
\text { Methorst, Rob }\end{array}$ & $\begin{array}{l}\text { Sinn und Unsinn von Shared Space - } \\
\text { Zur Versachlichung einer populären } \\
\text { Gestaltungsphilosophie; Teil } 1 \text { [Sense and nonsense about Shared } \\
\text { Space-For an objective view of a popular planning concept; part 1] }\end{array}$ \\
\hline $\begin{array}{l}\text { Gerlach, Jürgen } \\
\text { Boenke, Dirk } \\
\text { Leven, Jens } \\
\text { Methorst, Rob }\end{array}$ & $\begin{array}{l}\text { Sinn und Unsinn von Shared Space - } \\
\text { Zur Versachlichung einer populären } \\
\text { Gestaltungsphilosophie; Teil } 2 \text { [Sense and nonsense about Shared } \\
\text { Space-For an objective view of a popular planning concept; part 2] }\end{array}$ \\
\hline $\begin{array}{l}\text { Havik, Else M. } \\
\text { Melis-Dankers, Bart J. M. } \\
\text { Steyvers, Frank J. J. M. } \\
\text { Kooijman, Aart C. }\end{array}$ & $\begin{array}{l}\text { Accessibility of Shared Space for visually impaired persons: An } \\
\text { inventory in the Netherlands }\end{array}$ \\
\hline Imrie, Rob & Shared Space and the Post-politics of Environmental Change \\
\hline Imrie, Rob & $\begin{array}{l}\text { Auto-disabilities: The Case of Shared Space } \\
\text { Environments }\end{array}$ \\
\hline $\begin{array}{l}\text { Kaparias, Ioannis, } \\
\text { Bell, Michael G. H. } \\
\text { Miri, Ashkan } \\
\text { Chan, Carol } \\
\text { Mount, Bill }\end{array}$ & $\begin{array}{l}\text { Analysing the Perceptions of Pedestrians and Drivers to Shared } \\
\text { Space }\end{array}$ \\
\hline $\begin{array}{l}\text { Karndacharuk, Auttapone } \\
\text { Wilson, Douglas J. } \\
\text { Dunn, Roger }\end{array}$ & $\begin{array}{l}\text { A Review of the Evolution of Shared (Street) Space Concepts in } \\
\text { Urban Environments }\end{array}$ \\
\hline $\begin{array}{l}\text { Karndacharuk, Auttapone } \\
\text { Wilson, Douglas J. } \\
\text { Dunn, Roger }\end{array}$ & Analysis of pedestrian performance in shared-space environments \\
\hline $\begin{array}{l}\text { Moody, Simon } \\
\text { Melia, Steve }\end{array}$ & Shared Space - Research, Policy and Problems \\
\hline $\begin{array}{l}\text { Hammond, Victoria } \\
\text { Musselwhite, Charles }\end{array}$ & $\begin{array}{l}\text { The Attitudes, Perceptions and Concerns of Pedestrians and } \\
\text { Vulnerable Road Users to Shared Space: A Case Study from the } \\
\text { UK. }\end{array}$ \\
\hline Sastrawinata, A.C. & $\begin{array}{l}\text { Tracking and Analysing Behaviour of Pedestrians and Vehicles in a } \\
\text { Shared Space Environment for Model Calibration }\end{array}$ \\
\hline \multicolumn{2}{|l|}{ Guidance documents } \\
\hline Mairi, Joyce & Shared Space in Urban Environments - Guidance Note \\
\hline Department for Transport & Local Transport Note $1 / 11$ - Shared Space \\
\hline Jones, Phil & Manual for Streets 2: Wider Application of the Principles \\
\hline
\end{tabular}




\begin{tabular}{|c|c|}
\hline \multicolumn{2}{|l|}{ Young, Allan } \\
\hline Bad Architects Group & $\begin{array}{l}\text { Shared-Space-Konzepte in Österreich, der Schweiz und } \\
\text { Deutschland - Leitfaden [Shared space concepts in Austria, } \\
\text { Switzerland and Germany - Guidance note] }\end{array}$ \\
\hline $\begin{array}{l}\text { Forschungsgesellschaft für } \\
\text { Straßen- und } \\
\text { Verkehrswesen }\end{array}$ & $\begin{array}{l}\text { Hinweise zu Straßenräumen mit besonderem Überquerungsbedarf - } \\
\text { Anwendungsmöglichkeiten des "Shared Space" - Gedankens } \\
\text { [Notes on road spaces with special crossing requirements - } \\
\text { application possibilities of the "Shared Space" - idea] }\end{array}$ \\
\hline \multicolumn{2}{|l|}{$\begin{array}{l}\text { Reports and policy } \\
\text { documents }\end{array}$} \\
\hline Bosch Slabbers & $\begin{array}{l}\text { Städtebauliches Planungsverfahren Ortskern Bohmte } \\
\text { im Rahmen des EU - Projektes Shared Space } \\
\text { Abschlussdokumentation [Urban Development Planning Process for } \\
\text { Bohmte, Part of the EU Project Shared Space; Final Assessment] }\end{array}$ \\
\hline $\begin{array}{l}\text { Wallberg et al. / Sveriges } \\
\text { kommuner och landsting }\end{array}$ & $\begin{array}{l}\text { Shared Space: Trafikrum för Alla [Shared Space: Traffic Space for } \\
\text { All] }\end{array}$ \\
\hline Adamsson, Carolin & $\begin{array}{l}\text { Delad yta, dubbel yta? } \\
\text { En studie om Dragarbrunnsgatan i Uppsala utifrån konceptet shared } \\
\text { space [Divided Surface, doubled surface? } \\
\text { A study of Dragarbrunnsgatan in Uppsala based on the concept of } \\
\text { shared space] }\end{array}$ \\
\hline Shared Space & Shared Space: Room for Everyone \\
\hline Shared Space & Shared Space - From Project to Process \\
\hline Edquist, Jessica & $\begin{array}{l}\text { Potential application of Shared Space principles in urban } \\
\text { road design: effects on safety and amenity }\end{array}$ \\
\hline $\begin{array}{l}\text { Noordelijke Hogeschool } \\
\text { Leeuwarden }\end{array}$ & $\begin{array}{l}\text { The Laweiplein - Evaluation of the Reconstruction into a Square } \\
\text { with Roundabout }\end{array}$ \\
\hline $\begin{array}{l}\text { Gerlach, Jürgen } \\
\text { Ortlepp, Jörg } \\
\text { Voß, Heiko }\end{array}$ & $\begin{array}{l}\text { Shared Space - Eine neue Gestaltungsphilosophie für Innenstädte? } \\
\text { Beispiele und Empfehlungen für die Praxis [A New Design } \\
\text { Philosophy for City Centers? Examples and Recommendations for } \\
\text { Practice] }\end{array}$ \\
\hline $\begin{array}{l}\text { Gerlach, Jürgen } \\
\text { Kesting, Tabea } \\
\text { Kettler, Dietma } \\
\text { Leven, Jens } \\
\text { Boenke, Dirk }\end{array}$ & $\begin{array}{l}\text { Voraussetzungen für die Umsetzung von Gemeinschaftsstrassen in } \\
\text { Weiterentwicklung des Shared Space-Prinzips unter Beachtung der } \\
\text { großstädtischen Rahmenbedingungen der Freien und Hansestadt } \\
\text { Hamburg [Prerequisites for the Implementation of Community } \\
\text { Roads, Developing the Shared Space Principles in Compliance with } \\
\text { the Urban Conditions of the Free and Hanseatic City of Hamburg] }\end{array}$ \\
\hline $\begin{array}{l}\text { Imrie, Rob } \\
\text { Kumar, Marion }\end{array}$ & $\begin{array}{l}\text { Shared Space and Sight Loss: Policies and } \\
\text { Practices in English Local Authorities }\end{array}$ \\
\hline Besley, Eleanor & $\begin{array}{l}\text { Kerb Your Enthusiasm - Why Shared Space Doesn't Always Mean } \\
\text { Shared Surface, and Other Stories }\end{array}$ \\
\hline $\begin{array}{l}\text { Shore, Fiona } \\
\text { Uthayakumar, Kayleigh }\end{array}$ & Designing the Future - Shared Space : Operational Assessment \\
\hline $\begin{array}{l}\text { Dickens, Liz } \\
\text { Healy, Emma } \\
\text { Plews, Catherine } \\
\text { Uthayakumar, Kayleigh }\end{array}$ & $\begin{array}{l}\text { Designing the Future } \\
\text { Shared Space: Qualitative Research }\end{array}$ \\
\hline $\begin{array}{l}\text { Reid, Stuart } \\
\text { Kocak, Nazan }\end{array}$ & DfT Shared Space Project - Stage 1: Appraisal of Shared Space \\
\hline
\end{tabular}




\begin{tabular}{|c|c|}
\hline Hunt, Laura & \\
\hline $\begin{array}{l}\text { Myrberg, Grethe } \\
\text { van Winjgarden, Karin } \\
\text { Børrud, Elin } \\
\text { Lene, Stenersen }\end{array}$ & $\begin{array}{l}\text { Shared Space - Erfaringer Med "Shared Space" ved Kryssutforming } \\
\text { [Experiences with "Shared Space" in the Design of Street } \\
\text { Junctions] }\end{array}$ \\
\hline $\begin{array}{l}\text { Quimby, Allan } \\
\text { Castle, James }\end{array}$ & A Review of Simplified Streetscape Schemes \\
\hline Carol, Thomas & $\begin{array}{l}\text { Shared Surface Street Design: Report of Focus Groups held in } \\
\text { Holland }\end{array}$ \\
\hline $\begin{array}{l}\text { Deichmann, Jacob } \\
\text { Winterberg, Bjarne } \\
\text { Bredmose, Anette }\end{array}$ & $\begin{array}{l}\text { Shared Space - Safe Space; Meeting the Requirements of Blind and } \\
\text { Partially Sighted People in a Shared Space }\end{array}$ \\
\hline $\begin{array}{l}\text { Grey, Tom } \\
\text { Siddall, Emma }\end{array}$ & $\begin{array}{l}\text { Shared Space, Shared Surfaces and Home Zones from a Universal } \\
\text { Design Approach for the Urban Environment in Ireland. Key } \\
\text { Findings \& Recommendations }\end{array}$ \\
\hline Shared Space & Shared Space - Final Evaluation and Results \\
\hline Zimmermann, Tim & $\begin{array}{l}\text { Überblick aktueller Shared Space Projekte in Deutschland und } \\
\text { Ableitung von allgemeingültigen Gestaltungsvarianten und deren } \\
\text { Wirkung auf das Verhalten [Overview Over Current Shared Space } \\
\text { Projects in Germany and Derivation of Universal Design Variants } \\
\text { and their Effect on Behavior] }\end{array}$ \\
\hline Tyréns & Trafiksäkerhet ved Shared Space [Traffic safety in Shared Space] \\
\hline Rambøll & $\begin{array}{l}\text { Eksempelsamling - Shared Space [Example Collection - Shared } \\
\text { Space] }\end{array}$ \\
\hline Shared Space & Shared Space - Spatial quality - Places that Attract People \\
\hline Trafikverket & $\begin{array}{l}\text { Attraktiva Stadsrum för Alla - Shared Space [Attractive Urban } \\
\text { Spaces for All ] }\end{array}$ \\
\hline \multicolumn{2}{|l|}{ Theses (Master level) } \\
\hline Larsen, Vendel & $\begin{array}{l}\text { Best Practices ved Design af Shared Space [Best Practice for } \\
\text { Shared Space Design] }\end{array}$ \\
\hline Brenner, Andre & $\begin{array}{l}\text { Shared Space som Lomcept för Planering av det Offentliga Rummet } \\
\text { i Sverige [Shared Space as a Concept for Planning Public Space in } \\
\text { Sweden] }\end{array}$ \\
\hline $\begin{array}{l}\text { Hammarin, Petra } \\
\text { Warnelid, Annika }\end{array}$ & $\begin{array}{l}\text { Shared Space - Integrerade Trafikytor I Tätort. Jämförelse Mellan } \\
\text { Fiskatorget I Västervik och Stortorget i Ystad [Integrated Traffic } \\
\text { Surfaces in Urban Areas. Comparison between Fiskartorget In } \\
\text { Västervik and Stortorget in Ystad] }\end{array}$ \\
\hline \multicolumn{2}{|l|}{$\begin{array}{l}\text { Papers (mainly } \\
\text { conference proceedings) }\end{array}$} \\
\hline $\begin{array}{l}\text { Karndacharuk, Auttapone } \\
\text { Wilson, Douglas J. } \\
\text { Tse, M. }\end{array}$ & $\begin{array}{l}\text { Shared Space Performance Evaluation: Quantitative Analysis of } \\
\text { Pre-implementation Data }\end{array}$ \\
\hline $\begin{array}{l}\text { Karndacharuk, Auttapone } \\
\text { Wilson, Douglas J. } \\
\text { Dunn, Roger C. M. }\end{array}$ & $\begin{array}{l}\text { Safety Performance Study of a Shared Pedestrian and Vehicle } \\
\text { Space in New Zealand }\end{array}$ \\
\hline Barter, Paul & Earning a Public Space Dividend in the Streets \\
\hline Bliek, Desmond & $\begin{array}{l}\text { Impacts of Shared Space Design on Pedestrian and Motorist } \\
\text { Behaviour }\end{array}$ \\
\hline
\end{tabular}




\begin{tabular}{|c|c|}
\hline Dong, Weili & $\begin{array}{l}\text { Traffic Conflict and Shared Space: A Before- and After-Case Study } \\
\text { on Exhibition Road }\end{array}$ \\
\hline $\begin{array}{l}\text { Gilman, Celeste } \\
\text { Gilman, Robert }\end{array}$ & $\begin{array}{l}\text { Shared-Use Streets - An Application of "Shared Space" to an } \\
\text { American Small Town }\end{array}$ \\
\hline Heinz, Harald & Shared Space or Saved Space? \\
\hline $\begin{array}{l}\text { Hickman, Robin } \\
\text { Carson, Graham }\end{array}$ & $\begin{array}{l}\text { Shared Space in the Kent Downs: A New Approach to Streetscape } \\
\text { Design }\end{array}$ \\
\hline $\begin{array}{l}\text { Joyce, Mairi } \\
\text { Langwell, Todd }\end{array}$ & Technical Paper - Safety and Shared Spaces \\
\hline Kennedy, Janet V & Psychological Traffic Calming \\
\hline Schlabbach, Klaus & Shared Space \\
\hline Pauser, Wolfgang & $\begin{array}{l}\text { Shared Space, Die moralische Promenade [Shared Space, The } \\
\text { Moral Promenade] }\end{array}$ \\
\hline Pilz, Thomas & $\begin{array}{l}\text { Form, Halt, Respekt - Shared Space als Denkform in Architektur } \\
\text { und Raumplanung [Shape, Support, Respect - Shared Space as a } \\
\text { way of thinking in architecture and planning] }\end{array}$ \\
\hline $\begin{array}{l}\text { Lamíquiz, Daudén } \\
\text { José, Francisco } \\
\text { Porto Schettino, Mateus } \\
\text { Pozueta Echavarri, Julio }\end{array}$ & $\begin{array}{l}\text { New Forms of Shared Streets - Shared Space and its Application in } \\
\text { Madrid }\end{array}$ \\
\hline $\begin{array}{l}\text { Schönauer, Robert } \\
\text { Stubenschrott, Martin } \\
\text { Schrom-Feiertag, Helmut } \\
\text { Menšik, Karl }\end{array}$ & Social and Spatial Behaviour in Shared Spaces \\
\hline Tooby, David & Shared Space Performance Analysis, Port Macquarie NSW \\
\hline $\begin{array}{l}\text { Thomas, Christian } \\
\text { Wolff, Richard }\end{array}$ & $\begin{array}{l}\text { Homezones go downtown - The Evolution of Shared Spaces in } \\
\text { Switzerland }\end{array}$ \\
\hline \multicolumn{2}{|l|}{ Books } \\
\hline $\begin{array}{l}\text { Schmidt, Florian } \\
\text { Bechtler, Cornelius } \\
\text { Hänel, Anja } \\
\text { Laube, Marion } \\
\text { Pohl, Wolfgang }\end{array}$ & $\begin{array}{l}\text { Shared Space. [Shared Space. Examples and arguments for vibrant } \\
\text { public spaces] }\end{array}$ \\
\hline
\end{tabular}

'Langmyhr recommends the mediation between the public and diverse stakeholders in framing transport policy, where transport planning policy is negotiated and decisions for large-scale transport projects are communicated. I argue that such rhetorical mechanisms are can be observed not only in framing large-scale transport projects but also when negotiating challenging ideas. 